\title{
Identifying the optimal domestic cattle breed via multi-criteria decision making: the case of Turkey
}

\author{
Arif Selim EREN ${ }^{1)}$ \\ ${ }^{I}$ Faculty Member in Faculty of Economics and Administrative Sciences, Kahramanmaraş Sütçü İmam \\ University, Turkey
}

\begin{abstract}
In today's economy, agriculture plays a very crucial role as it has subsidiary effects on the life of people. Breeding and developing the optimal animal race is a challenge which is being faced by many practitioners, as they have to cope with the rising costs and rivalry. In terms of production planning, choosing the right breed to be fed is a highly important factor in gathering the desired results. The present study aims to define the optimal cattle breed by using multi-criteria decision making. In order to do so, the characteristics of domestic Turkish breeds are obtained and analyzed via TOPSIS method. The findings imply that Zavot Breed is the best option to be developed. Moreover, the present study includes some research implications for future research.
\end{abstract}

Keywords: TOPSIS, Domestic Cattle Breeds, Turkey

\section{Introduction}

Globalization effects the social life in many ways. The economic structure of the present day requires minimizing the costs and maximizing the profits by applying the optimal production parameters. Agriculture is a promising sector as it can sustain as long as humanity continue.

There are some prior research discussing the factors affective in breeding and obtaining greater yield (Watson, 1994: 24; Nehring et. al., 2014: 311; Madelena, 1989: 183). These factors are being modified by the use of technology and genetically modified agricultural technologies are being used globally (Cai et. al., 2017: 317). All of these research can be categorized into three main types. The initial one covers the specifications of a specific breed. The second focuses on the factors affecting yield. The last one deals with the technological aspects. Moving from here, the present study aimed to come up with the best domestic breed by the use of multi-criteria decision making. This study is identical as it is the first study to cover operations research methodology on the topic. In order to achieve the goals of the study, the author used official data obtained from TAGEM. The data is analyzed via TOPSIS method. The results indicate that Zavot breed is the best to have higher parameter values.

\section{Literature Review}

The literature is rich in studies focusing on one dimension of the yields. However, if someone is about to make investment on a breed, the literature needs more explanative and comparable data. The present study included a literature review of the former studies in literature. The findings are as follows;

Monson et. al. (2004) focused on textural meat quality and examined the ageing time in the breeds. They found that ageing of meat has an effect on the number of microorganisms in the texture. Although it is not directly related to the focus of the present study, one can have the idea of the importance of breeding in farms. On the other hand, Yaylak \& Kumlu (2005: 55) conducted a research on the lactation yield of black race. They focused on some environmental factors affecting lactation. They concluded that before-calving period is to have the highest yield. Similar to the former one, İnci et. al. (2007: 203) investigated the lactation and fertility of the same race. Also, Uygur (2004: 23) focused the same topic. Goyache \& Gutierrez (2001: 489) also made a research on the yield of a specific cattle race. Besides these, Koç (2006: 1) made a similar research in another location with similar cattle race. Akman et. al. (2001: 173) also has a similar research.

Moreover, Madelena (1989: 183) made a research on cattle breed resource utilization for dairy products in Brazil. The author makes a comparison between Holstein-Friesian and Guzera breeds. The study implies that for better production parameters, these breeds can be crossed. Similar to the former study, Nehring et. al. (2014: 311) discussed the economic factors in breeding. Zhong et. al. (2013: 526) also focused on the factors affecting milking yield. Besides these Cai et. al. (2017: 317) suggested the use of genetically modified agricultural technologies. Besides these, Galiç et. al. (2005: 87) studied calving. They concluded that the earlier the breed is ready for calving, the more productive is the breed. This finding is used in defining the parameters in the present study. Similar to the former one, Yllmaz et. al. (2003: 169) investigated the factors affecting yield in dairy products. They assert that the breeding is crucial for better production. Just like others, Subratty \& Gurib, (2003: 80) asserted some factors affecting the perceptions of the customers. These factors can be utilized for further research. Choudhury, (2011: 91) also mentions the essentials of supply chains in food production. Moreover, 
Goddard et. al. (2016: 1533) discusses the same topic. Şekerden et. al. (1999: 505) also defines some factors affecting the yield in milking. Lastly, Eyduran et. al. (2005: 61) mentions the duration of milking period.

Furthermore, Seaman et. al. (2002: 881) conducted a research on the impact of breed type, sex, method of rearing, winter nutrition and subsequent grazing treatment on the rate of carcass cooling and eating quality of beef. They conclude that the mentioned factors are important in obtaining better production results. Watson (1994: 24) also mentions the importance of breeding in obtaining greater yield.

To sum all up, former studies can be classified into three main categories. The first one consists of studies focusing on a specific cattle race. The second covers the factors affecting the yield in meat and milk production. The last one covers the genetically modified breeding and the use of technology in agriculture. The historical analysis of these research indicate that the scope of modern agriculture will be on the genetics and economic factors in yield. Thus, the present study will be identical as it tries to combine all of the Turkish domestic breed parameters via operations research methodology.

\section{Basic Domestic Cattle Breeds in Turkey}

Turkey is a fertile country for cattle breeding. Many people are earning their lives by farming. This part of the study includes some characteristics of domestic cattle breeds. In Table 1, these characteristics are depicted.

Table 1. Characteristics of Cattle Breeds

\begin{tabular}{|c|c|c|c|c|c|c|c|}
\hline & $\begin{array}{l}\text { South } \\
\text { Anatolian } \\
\text { Red }\end{array}$ & $\begin{array}{l}\text { Indigenous } \\
\text { South } \\
\text { Yellow }\end{array}$ & $\begin{array}{l}\text { Indigenous } \\
\text { Black }\end{array}$ & $\begin{array}{l}\text { East } \\
\text { Anatolian } \\
\text { Red }\end{array}$ & Zavot & Grey race & $\begin{array}{l}\text { Anatolian } \\
\text { Water } \\
\text { Buffalo }\end{array}$ \\
\hline Cidago Height $(\mathrm{cm})$ & 137,5 & 110 & 105 & 115 & 122,75 & 121,5 & 132,5 \\
\hline Body Length $(\mathrm{cm})$ & 137,5 & 115 & 110 & 127,5 & 137,75 & 117,5 & 140 \\
\hline Birth Weight (kg) & 25 & 14,5 & 18,5 & 19,5 & 22 & 24 & 30 \\
\hline Mature Live Weight (kg) & 487,5 & 200 & 300 & 350 & 430 & 412,5 & 500 \\
\hline Age of giving birth (months) & 25 & 33 & 26 & 25 & 26 & 26 & 25 \\
\hline Daily Live Weight Increase (g) & 800 & 600 & 800 & 800 & 862,5 & 1050 & 575 \\
\hline Lactation Milk Yield (kg) & 2000 & 625 & 1050 & 950 & 2800 & 1100 & 900 \\
\hline Lactation Time (days) & 225 & 190 & 250 & 210 & 287,5 & 220 & 225 \\
\hline Milk Fat Percentage $(\%)$ & 4 & 3,5 & 4,5 & 4,5 & 4 & 4,5 & 7 \\
\hline
\end{tabular}

As demonstrated in Table 1, the cidago height, body length, birth weight, mature live weight, age of giving birth, daily live weight increase, lactation milk yield, lactation time and milk fat percentage are listed according to official statistics (TAGEM, 2009).

The breeds are reviewed in terms of general features. First of all, The South Anatolian Red is reported to be prolific both in meat and milk. It is widely being fed in the Southern parts of the country. Similarly, Indigenous Southern Yellow is also productive both in meat and milk production. This breed is being fed in the Eastern part of the country. On the other hand Indigenous Black is another productive race in milk and meat production. It is being grown in the middle parts of the country. Just like others, East Anatolian Red is being fed in the Eastern parts of the country. On the other hand, Zavot is being fed in the same region. This breed has some superior qualities when compared to the other breeds. Grey race is the particular breed of Thracian region. Besides these, the Anatolian Water Buffalo is being fed in the whole country. Although there is a regional distribution for all of these breeds, there cannot cope with the imported races. Furthermore, they cannot afford the international standards because of many factors, namely untutored breeders, malnutrition and not paying attention to develop better breeds.

\section{Methodology}

In the former parts of the study, the context is introduced and the literature is reviewed. The findings and methodology of the former studies are adopted and the features of cattle breeds are assessed. In this part of the study, these features are going to be compared by using TOPSIS method. In order to do so, breeders are interviewed they are asked to rank the parameters that are obtained from TAGEM. The weights are turned into percentages and minimized into one.

\begin{tabular}{|l|l|l|l|l|l|l|l|l|}
\hline \multicolumn{7}{|c|}{ Table 2. Weights of the criteria } \\
\hline 0.12987 & 0.12987 & 0.116883 & 0.12987 & 0.090909 & 0.12987 & 0.077922 & 0.103896 & 0.090909 \\
\hline
\end{tabular}

According to these weights the breeders consider cidago height, body length, mature live weight and daily live weight increase at the same weight. The calculations include six stage in TOPSIS (Ertuğrul and Özçil; 2014: 271-273; Şimşek et al., 2015: 140-142; Gökdalay; 1999: 162; Jahanshahloo et al. 2006: 1377-1378; Supçiller and Çapraz, 2011: 9-12); 
Stage 1 : Creating Decision Matrices

$U_{i j}=\left[\begin{array}{cccc}u_{11} & u_{12} & \ldots & u_{1 j} \\ u_{21} & u_{22} & \ldots & u_{2 j} \\ \vdots & \vdots & \ddots & \vdots \\ u_{i 1} & u_{i 2} & \ldots & u_{i j}\end{array}\right]$

Here, "i" designated the number of alternatives, " $j$ " stands for the number of criteria.

Stage 2: Normalizing Decision Matrices

Normalization is calculated as in the following formula;

$$
\begin{aligned}
r_{i j} & =\frac{u_{i j}}{\sqrt{\sum_{i=1}^{m} u_{i j}^{2}}} \quad j \quad j=1, \ldots, m \quad j=1, \ldots, n \\
R_{i j} & =\left[\begin{array}{cccc}
r_{11} & r_{12} & \ldots & r_{1 j} \\
r_{21} & r_{22} & \ldots & r_{2 j} \\
\vdots & \vdots & \ddots & \vdots \\
r_{i 1} & r_{i 2} & \ldots & r_{i j}
\end{array}\right]
\end{aligned}
$$

Stage 3: Weighting decision matrices

$\mathrm{X}_{\mathrm{ij}}=\mathrm{Y}_{\mathrm{j}} \mathrm{r}_{\mathrm{ij}} \quad \mathrm{i}=1,2, \ldots, \mathrm{m} \quad \mathrm{j}=1,2, \ldots, \mathrm{n}$

Her $Y_{j}$ stands for the weight of the $j^{\text {th }}$ criteria.

Stage 4: Calculation of Positive and Negative Ideal Solutions

The positive-ideal solution value $\mathrm{U}^{+}$and negative-ideal solution value $\mathrm{U}^{-}$are calculated as follows;

$\mathrm{U}^{+}=\left\{\mathrm{X}_{1}^{+}, \mathrm{X}_{2}^{+}, \ldots, \mathrm{X}_{\mathrm{j}}^{+}, \ldots, \mathrm{X}_{\mathrm{n}}^{+}\right\}$(maximum)

$\mathrm{U}^{-}=\left\{\mathrm{X}_{1}^{-}, \mathrm{X}_{2}^{-}, \ldots, \mathrm{X}_{\mathrm{j}}^{-}, \ldots, \mathrm{X}_{\mathrm{n}}^{-}\right\}$(minimum)

Stage 5: Calculation of the distance to the ideal points

The distance between the positive ideal solution point $\mathrm{T}_{\mathrm{i}}^{+}$and negative ideal solution point $\mathrm{T}_{\mathrm{i}}^{-}$are calculated as follows;

$\mathrm{T}_{\mathrm{i}}^{+}=\sqrt{\sum_{\mathrm{j}=1}^{\mathrm{n}}\left(\mathrm{X}_{\mathrm{ij}}-\mathrm{X}_{\mathrm{j}}^{+}\right)^{2}} \quad \mathrm{i}=1,2, \ldots, \mathrm{m}$
$\mathrm{T}_{\mathrm{i}}^{-}=\sqrt{\sum_{\mathrm{j}=1}^{\mathrm{n}}\left(\mathrm{X}_{\mathrm{ij}}-\mathrm{X}_{\mathrm{j}}^{+}\right)^{2}} \quad \mathrm{i}=1,2, \ldots, \mathrm{m}$

Stage 6: Calculation of degree of proximity to ideal solution It is done as follows:

$\mathrm{H}_{\mathrm{i}}^{+}=\frac{\mathrm{T}_{\mathrm{i}}^{-}}{\mathrm{T}_{\mathrm{i}}^{-}+\mathrm{T}_{\mathrm{i}}^{+}} \quad \mathrm{i}=1,2, \ldots, \mathrm{m}$

Here, $\mathrm{H}_{\mathrm{i}}^{*}$ takes a value between 0 and $1 . \mathrm{H}_{\mathrm{i}}^{*}=1$ stands for the ideal positive solution and $\mathrm{H}_{\mathrm{i}}^{*}=0$ designates ideal negative solution.

The decision matrix is constituted as following the stages above. The notations in the formula " $\mathrm{u}_{\mathrm{ij}}$ " are replaced with the cattle breeds and the features are also placed.

Table 3. Normalized Martix

\begin{tabular}{|l|l|l|l|l|l|l|l|l|l|}
\hline $1: \mid$ & 0.42918 & 0.409275 & 0.42151 & 0.465828 & 0.353837 & 0.378937 & 0.496053 & 0.36742 & 0.322329 \\
\hline $2: \mid$ & 0.343344 & 0.342303 & 0.244476 & 0.191109 & 0.467064 & 0.284203 & 0.155017 & 0.310266 & 0.282038 \\
\hline $3: \mid$ & 0.327737 & 0.32742 & 0.311917 & 0.286663 & 0.36799 & 0.378937 & 0.260428 & 0.408245 & 0.36262 \\
\hline $4:$ & 0.358951 & 0.37951 & 0.328778 & 0.33444 & 0.353837 & 0.378937 & 0.235625 & 0.342926 & 0.36262 \\
\hline $5: \mid$ & 0.383141 & 0.41002 & 0.370928 & 0.410884 & 0.36799 & 0.408542 & 0.694474 & 0.469482 & 0.322329 \\
\hline $6: \mid$ & 0.379239 & 0.349744 & 0.404649 & 0.394162 & 0.36799 & 0.497355 & 0.272829 & 0.359256 & 0.36262 \\
\hline $7: \mid$ & 0.413573 & 0.416717 & 0.505812 & 0.477772 & 0.353837 & 0.272361 & 0.223224 & 0.36742 & 0.564076 \\
\hline
\end{tabular}

Initially the normalized values are calculated and these are depicted Table 3.

Table 4. Weighted Matrix

\begin{tabular}{|l|l|l|l|l|l|l|l|l|l|}
\hline $1:$ & 0.055738 & 0.053153 & 0.049267 & 0.060497 & 0.032167 & 0.049213 & 0.038654 & 0.038174 & 0.029303 \\
\hline $2: \mid$ & 0.04459 & 0.044455 & 0.028575 & 0.024819 & 0.04246 & 0.03691 & 0.012079 & 0.032235 & 0.02564 \\
\hline $3:$ & 0.042563 & 0.042522 & 0.036458 & 0.037229 & 0.033454 & 0.049213 & 0.020293 & 0.042415 & 0.032966 \\
\hline $4:$ & 0.046617 & 0.049287 & 0.038429 & 0.043434 & 0.032167 & 0.049213 & 0.01836 & 0.035629 & 0.032966 \\
\hline $5: \mid$ & 0.049759 & 0.053249 & 0.043355 & 0.053362 & 0.033454 & 0.053057 & 0.054115 & 0.048777 & 0.029303 \\
\hline $6: \mid$ & 0.049252 & 0.045421 & 0.047297 & 0.05119 & 0.033454 & 0.064592 & 0.021259 & 0.037325 & 0.032966 \\
\hline $7: \mid$ & 0.053711 & 0.054119 & 0.059121 & 0.062048 & 0.032167 & 0.035372 & 0.017394 & 0.038174 & 0.05128 \\
\hline
\end{tabular}


The values in Table 3 are recalculated according to the weights and the weighted matrix is obtained.

Table 5. Relative Proximities

\begin{tabular}{|l|l|}
\hline South Anatolian Red & 0.616998 \\
\hline Indigenous South Yellow & 0.603928 \\
\hline Indigenous Black & 0.320905 \\
\hline East Anatolian Red & 0.358611 \\
\hline Zavot & 0.658833 \\
\hline Grey race & 0.516683 \\
\hline Anatolian Water Buffalo & 0.547866 \\
\hline
\end{tabular}

Lastly the relative proximities are obtained and the maximum relative proximity is reported for Zavot Breed. Breeders should pay attention to hybrid or pure instances of this breed.

\section{Conclusion, Limitations, Ideas for future research}

In production management selection of the production factors are noteworthy. Firms should optimize the inputs of production lines in order to obtain more yield. In cattle breeding the selection of the cattle breed is prominent as the cost of breeding is increasing day by day. Moving here, this study aimed to compare the domestic cattle breeds of Turkey by using the official statistics. In order to do so, initially a literature review is carried out and the characteristics of the breeds are determined. Then, interviews are conducted with breeders and they are asked to rank the qualities mentioned by TAGEM. These ranks are turned into weights and analyzed via TOPSIS. The results of the study indicate that Zavot breed is the optimal race to be improved. Besides this contribution the present study has some limitations. The use of imported herds are widely being used in the field. This study excludes them and future studies can inclose them into the context. The criteria used for benchmarking can also be expanded. The use of other analysis techniques such as AHP can also make contribution in order to see the differences between the two tests. Moreover, researchers can use the weights of the present research in their work. Lastly, the interviews can be expanded to more breeders and this may cause higher precision.

\section{References}

[1]. Akman, N., (2011), "Hayvan Islahı”, Hayvan Yetiştirme, ISBN 978-975-06-0927-5, Anadolu Üniversitesi Yayınları, Eşkişehir, pp. $1-27$.

[2]. Akman, N., Ulutaş, Z., Efil, H. \& Biçer, S., (2001), “Gelemen Tarım İşletmesinde Yetiştirilen Siyah-Alaca sürüsünde süt ve döl verimi özellikleri”, Atatürk Üniv. Ziraat Fak. Derg., 32(2), pp. 173-179.

[3]. Cai, J., Hu, R., Huang, J. \& Wang, X., (2017) "Innovations in genetically modified agricultural technologies in China's public sector: Successes and challenges", China Agricultural Economic Review, 9(2), pp.317-330.

[4]. Choudhury, M. A., (2011) "Some structural issues in demand and supply of global food production", Journal of Economic Studies, 38(1), pp.91-113.

[5]. Ertuğrul, İ. \& Özçil, A. (2014). Çok Kriterli Karar Vermede TOPSIS ve VIKOR Yöntemleriyle Klima Seçimi. Çankırı Karatekin Üniversitesi İktisadi ve İdari Bilimler Fakültesi Dergisi, 4(1), 267-282.

[6]. Eyduran, E., Özdemir, T., Yazgan, K. \& Keskin, S., (2005), "Siyah Alaca İnek Sütündeki Somatik Hücre Sayısına Laktasyon Sırası ve Dönemin Etkisi”, YYÜ Vet Fak Derg., 16 (1), pp. 61-65.

[7]. Galiç, A., Şekeroğlu, H. \& Kumlu, S., (2005), “İzmir İli Siyah Alaca Irki Sığır Yetiştiriciliğinde İlk Buzağılama Yaşı Ve Süt Verimine Etkisi”, Akdeniz Üniv. Ziraat Fak. Derg. 18(1), pp. 87-93.

[8]. Goddard, E., Boaitey, A., Hailu, G. \& Poon, K., (2016) "Improving sustainability of beef industry supply chains", British Food Journal, 118(6), pp.1533-1552.

[9]. Gökdalay, M.H., (2009). Havaalanlarının Performans Analizinde Bulanık Ölçütlü Karar Verme Yaklaşımı, İstanbul Teknik Üniversitesi Mühendislik Dergisi, 8(6), 157-168.

[10]. Goyache, F. \& Gutierrez, J.P., (2001), "Heritability of Reproductive traits in Asturiana De Los Valles beef cattle Breed", Arch. Tierz. Dummerstorf, 44(5), pp. 489-496.

[11]. İnci, S., Kaygısız, A., Efe, E. \& Baş, S., “Altınova Tarım İşletmesinde Yetiştirilen Esmer Sığırların Süt ve Döl Verim Özellikleri”, Tarım Bilimleri Dergisi, 13(3), pp. 203-212.

[12]. Jahanshahloo, G.R., Hosseinzadeh Lotfi, F. ve Izadikhah, M. (2006). An Algorithmic Method To Extend TOPSIS for DecisionMaking Problems with İnterval Data, Applied Mathematics and Computation, 175 (2), 1375-1384.

[13]. Koç, A., (2006), "Aydın İlinde Yetiştirilen Siyah Alaca ve Esmer Irkı Sığırların Laktasyon Süt Verimleri ve Somatik hücre Sayıları", Hayvansal Üretim, 47(2), pp. 1-8.

[14]. Madelena, F.E., (1989), "Cattle Breed Resource Utilization For Diary Production in Brazil”, Supplement, 12(3), pp. 183-220.

[15]. Monson, F., Sanudo, C. \& Sierra, I., (2004), "Influence of cattle breed and ageing time on textural meat quality", Meat Science, 68(1), pp. 595-602.

[16]. Nehring, R., Gillespie, J., Hallahan, C., Harris, J.M. \& Erickson, K., (2014) "What is driving economic and financial success of US cow-calf operations?", Agricultural Finance Review, 74(3), pp.311-325.

[17]. Özdemir M., (2014) "TOPSIS, Operasyonel, Yönetsel ve Stratejik Problemlerin Çözümünde Çok Kriterli Karar Verme Yöntemleri”, pages : 133-153, Dora Basım-Yayın Dağıtım, Bursa.

[18]. Seaman, C.E.A., Hunter, E.A., Hinks, C.E. Hughes, A.H., Lowman, B.G., (2002) "The impact of breed type, sex, method of rearing, winter nutrition and subsequent grazing treatment on the rate of carcass cooling and eating quality of beef", British Food Journal, 104(11), pp.881-897.

[19]. SSekerden, Ö., Erdem, H., Kankurdan, B. \& Özlü, B., (1999), “Anadolu Mandalarında Süt Kompozisyonunu Etkileyen Faktörler ve Süt Kompozisyonunun Laktasyon Dönemlerine Göre Degisimi”, Tr. J. of Veterinary and Animal Sicences, 23(1), pp. 505-509. 
[20]. Şimşek, A., Çatır, O. ve Ömürbek, N. (2015). Topsis ve Moora Yöntemleri İle Tedarikçi Seçimi: Turizm Sektöründe Bir Uygulama, Balıkesir Üniversitesi Sosyal Bilimler Enstitüsü Dergisi, 18(33), 133-161.

[21]. Subratty, A.H. \& Gurib, F.B.H., (2003) "Consumers' concern about meat and meat products quality offered for sale in Mauritius", Nutrition \& Food Science, 33(2), pp.80-83.

[22]. Supçiller, A.A. ve Çapraz, O. (2011). Ahp-Topsıs Yöntemine Dayalı Tedarikçi Seçimi Uygulaması, İstanbul Üniversitesi İktisat Fakültesi Ekonometri Ve İstatistik Dergisi, 13 (12. Uluslararası Ekonometri, Yöneylemaraştırması, İstatistik Sempozyumu Özel Sayıs1, 1-22.

[23]. TAGEM, (2009), "Türkiye Evcil Hayvan Genetik Kaynakları”, Ankara, p. 100.

[24]. Uygur, A.M., (2004), “Süt Sığırcilığı Sürü Yönetiminde Döl Verimi”, Hayvansal Üretim, 45(2), pp. 23-27.

[25]. Watson, M.J., (1994) "Fostering Leaner Red Meat in the Food Supply", British Food Journal, 96(8), pp.24-32.

[26]. Yaylak, E. \& Kumlu, S., (2005), "Siyah Alaca Sığırları 305 Günlük Süt Verimine Vücut Kondisyon Puanı ve Bazı Çevre Faktörlerinin Etkisi”, Ege Üniv. Ziraat. Fak. Derg., 42(3):55-66.

[27]. Yılmaz, İ., Dağıstan, E., Koç, B. \& Özel, R., (2003), "Hatay İlinde Projeli Ve Projesiz Süt Sığırcıllğı Yapan İşletmelerin Süt Sığırcılığı Üretim Faaliyetlerinin Ve Faktör Verimliliklerinin Analizi”, Akdeniz Üniv. Ziraat Fak. Derg. 16(2), pp. 169-178.

[28]. Zhong, Z., Chen, S. \& Kong, X., (2013) "Production pattern, transaction style and raw milk quality: An empirical study based on a "comprehensive quality perspective”", China Agricultural Economic Review, 5(4), pp.526-542. 